\title{
DINAMIKA SOSIAL BUDAYA MASYARAKAT DESA ADAT PENGLIPURAN DI ERA GLOBALISASI
}

\section{Fitrotul Fajrin $\bowtie$}

Social Studies Education Universitas Negeri Semarang

\begin{tabular}{l} 
Info Artikel \\
\hline Sejarah Artikel: \\
Disubmit: September \\
2021 \\
Direvisi: Oktober 2021 \\
Diterima: November \\
2021 \\
\\
\hline Keywords: \\
Globalization; Traditional \\
Villages; Socio-Cultural \\
Dynamics
\end{tabular}

Dynamics

\begin{abstract}
Abstrak
Penelitian ini bertujuan untuk menjelaskan dan memahami dinamika sosial budaya kehidupan masyarakat desa adat Penglipuran dan Tenganan yang masih bertahan dalam kehidupan tradisional serta tetap melestarikan adat istiadat di tengah era Globalisasi. Metode penelitian yang digunakan yaitu kualitatif deskriptif dengan metode pengumpulan data yang digunakan adalah menggunakan observasi, wawancara, dan dokumentasi. Hasil penelitian diketahui bahwa, meskipun masyarakat desa Penglipuran sangat memegang teguh budaya lokal tetapi mereka tidak tertinggal oleh kemajuan zaman hal ini dapat dilihat dari keadaan sosialnya. Masyarakat Penglipuran menjadikan kebudayaan lokal mereka sebagai alat untuk menyaring budaya yang timbul dari adanya interaksi global di zaman modern serta menjadi alat dalam memperkuat ketahanan sosial budaya dalam rangka menjaga dan melestarikan kebudayaan dari nenek moyang.
\end{abstract}




\section{PENDAHULUAN}

Menurut kodratnya manusia adalah makhluk sosial atau makhluk bermasyarakat, selain itu juga diberikan yang berupa akal dan pikiran untuk berkembang dan dapat dikembangkan. Manusia dikatakan sebagai makhluk sosial menurut Arsana (2002:112) dikarenakan pada diri manusia ada dorongan dan kebutuhan untuk berhubungan (interaksi) dengan orang lain. Dewasa ini di Indonesia pada umumnya dan di Bali pada khususnya sedang mengalami suatu perubahan yang signifikan disegala bidang. Globalisasi yang telah melanda dunia saat ini menyebabkan batas-batas suatu wilayah ataupun negara seolah-olah semakin transparan. Globalisasi terbangun oleh interaksi sosial yang melibatkan nilai-nilai sosio-kultural individu atau kelompok yang melintasi batas komunikasinya untuk berhubungan dengan entitas lain (Rahmawati, 2010: 110). Hal ini membawa dampak pada kehidupan masyarakatnya. Rasa aman, nyaman dan damai, serta kehidupan sejahtera dan harmonis yang menjadi dambaan setiap orang menjadi sesuatu yang semakin sulit diperoleh. Sesungguhnya untuk mewujudkan tujuan tersebut merupakan tanggungjawab semua umat manusia.

Suneki (2012: 1) mengungkapkan budaya global ditandai oleh integrasi budaya lokal ke dalam suatu tatanan global. Menurut Nurhaida (2015:15) berbicara mengenai tantangan era Globalisasi dimana adanya integrasi budaya local dalam proses ini, setiap bangsa akan berusaha menyesuaikan budaya dan tradisi merekadengan perkembangan baru sehingga mereka dapat melanjutkan kehidupan dan menghindarikehancuran.Terkenalnya Bali hingga ditingkat internasional tidak serta merta memberikan dampak yang positif, akibat dari hal ini masyarakat Bali sendiri tidak luput dari dampak proses globalisasi yang seakan memaksa moral orang-orang Bali itu sendiri untuk mengikuti keadaan. Proses globalisasi memberikan banyak kelonggaran dan kebebasan yang hampir tidak terbatas disegala bidang yang mempengaruhi nilai-nilai yang tertanam di dalam benak-benak masyarakat Bali. Masyarakat adat Bali sebagai masyarakat sosial, dalam peradabannya juga memiliki norma yang mengatur kehidupannya dalam peradaban sejak peradabannya juga memiliki norma yang mengatur kehidupannya dalam peradaban sejak jaman dikenalnya kebudayaan yang terkenal dengan kosmologi Tri Hita Karana dan merupakan falsafah hidup yang bertahan hingga kini walaupun berada dalam konsep-konsep perubahan sosial yang selalu berdinamika sebagai salah satu ciri atau karakter peradaban. Falsafah Tri Hita Karana menurut Dewa Putu E.B.P (2012:2) memiliki konsep yang dapat melestarikan keanekaragaman budaya dan lingkungan ditengah hantaman globalisasi dan homogenisasi. Tri Hita Karana terbentuk dari kata tri yang berarti tiga, hita berarti kebahagiaan, dan karana yang berarti sebab atau yang menyebabkan, sehingga dapat dimaknai sebagai tiga penyebab kebahagiaan.

Penglipuran merupakan contoh dari desa adat yang ada di Bali. Desa ini masih memegang teguh konsep Tri Hita Karana terutama dalam kehidupan sosial budayanya. Salah satu konsep Tri Hita Karana yakni konsep Pawongan yang mengatur hubungan manusia dengan manusia. Di desa adat ini dalam melakukan interaksi dengan sesamanya sangat berprinsip pada konsep pawongan. Masyarakat desa Penglipuran kaya akan tradisi dan nilai-nilai budaya lokal. Meskipun mereka sangat memegang teguh budaya lokal tetapi mereka tidak tertinggal oleh kemajuan zaman hal ini dapat dilihat dari keadaan sosialnya. Berdasarkan latar belakang di atas maka permasalahan dalam penelitian ini difokuskan pada konsep pawongan sebagai wujud dinamika sosial budaya masyarakat desa adat Penglipuran di era globalisasi.

\section{METODE}

Jenis penelitian yang digunakan dalam penelitian ini adalah Kualitaitf dengan pendekatan Etnografi (Ethnography). Fokus penelitian ini menekanakan pada gambaran umum dari Desa Panglipuran dan Tenganan, bagaimana kehidupan sosial yang ada di Desa Penglipuran dinamika sosial budaya pada nilai dan norma, statifikasi soaial, deferansasi, lembaga/ organisasi/ kelompok sosial, sistem 
pernikahan, sitem kekerabatan, sistem mata pencaharian, sisitem pengetahuan, sistem teknologi dan peralatan.

\section{PEMBAHASAN}

Penglipuran berasal dari kata penglipur dan lara. Penglipuran merupakan tempat menghibur di kala duka lara, di samping karena penduduknya sering mendapat tugas menghibur Raja pada saat-saat Raja menghadapi berbagai permasalahan. Desa Penglipuran terletak di wilayah Kelurahan Kubu, Kecamatan Bangli Kabupaten Bangli Provinsi Bali. Desa Penglipuran berada pada jarak $45 \mathrm{~km}$ dari Ibu Kota Provinsi Bali dan $5 \mathrm{~km}$ dari Ibu Kota Kabupaten Bangli. Desa ini dapat dicapai dengan menggunakan mobil atau sepeda motor dengan kondisi jalan yang telah diaspal. Batas-batas wilayah Desa Penglipuran adalah di sebelah utara berbatasan dengan Desa Adat Kayang; di sebelah timur berbatasan dengan Desa Adat $\mathrm{Kubu}$; di sebelah selatan berbatasan dengan Desa Ada Cempaga; dan di sebelah barat berbatasan dengan Desa Adat Cekeng.

Secara geografi Desa Penglipuran terletak pada koordinat $08^{\circ} 08^{\circ} 30^{\circ}-08^{\circ} 31^{\circ} 07^{\circ}$ lintang selatan dan $115^{\circ} 13^{\circ} 43^{\circ}-115^{\circ} 27^{\circ} 24^{\circ}$ bujur timur dengan ketinggian 500-625 meter di atas permukaan laut. Berdasarkan profil, Desa Penglipuran memiliki luas wilayah kurang lebih $112 \mathrm{Ha}$ yang tata guna lahannya meliputi lahan pertanian, kawasan hutan, pemukiman, dan tempat suci. Luas wilayah tersebut didominasi oleh lahan pertanian yang memiliki luas 50ha berupa lahan kering atau tegalan. Kawasan hutan di Desa Penglipuran dengan luas 4ha dan hutan bambu dengan luas 45 ha. Pemukiman penduduk yang terletak di tengah wilayah Desa Penglipuran memiliki luas 9ha. Tempat suci di Desa Penglipuran seluas 4 ha.

Dinamika sosial pada yang dibahas nilai dan norma, statifikasi soaial, deferansasi, lembaga/ organisasi/ kelompok sosial, sistem pernikahan, sitem kekerabatan, sistem mata pencaharian, sisitem pengetahuan, sistem teknologi dan peralatan yang ada d Desa Penglipuran. Sedangkan Dnamika Budaya yang dibahas adaah adat istiadat, hukum adat dan kesenian.

\section{Dinamika Sosial Desa Adat Penglipuran Nilai dan Norma}

Nilai dan norma yang ada di masyarakat desa Penglipuran didasarkan pada konsep ajaran agama Hindu Tri Hita Karana, yaitu tiga hal yang menyebabkan kebaikan, diantaranya hubungan manusia dengan Tuhan, hubungan manusia dengan manusia dan hubungan manusia dengan lingkungan. Konsep tersebut digunakan oleh masyarakat sebagai pedoman orientasi dan motivasi dalam bersikap dan bertingkah laku.

Nilai-nilai sosial yang tumbuh di masyarakat yang mengandung makna luhur yang mendasari dalam kehidupan sehari-hari yaitu Tat twam asi yang merupakan konsep tentang saling menghargai antara sesama manusia, adanya toleransi dan hidup saling berdampingan. Salunglung Sebayantaka yaitu suatu konsep yang mengandung makna rasa sepenanggungan atau senasib. Beriuk Siu merupakan konsep yang mengandung makna persatuan dan kekompakan, dalam masyarakat. Menyama Braya konsep ini mengandung makna yang begitu mendalam, arti nyama braya yaitu persaudaraan. Hukum Karma Phala yaitu konsep dalam agama Hindu yang percaya dengan hasil dari perbuatan, dimana bila kita berbuat baik maka hasilnya yang diterima adalah kebaikan dan sebaliknya jiga keburukan yang kita lakukan maka keburukanlah yang akan kita terima. Bhakti Marga, hal ini memiliki arti bakti terhadap negara, pemerintah, dan agama. Karya Marga, yaitu suatu nilai yang mendorong solidaritas warga masyarakat untuk berbuat atau berkarya guna menjaga desanya.

Nilai dan norma di atas kebanyakan muncul dari ajaran agama Hindu. Hal tersebut sangat diyakini oleh masyarakat khususnya Bali, bila ada pelanggaran terhadap norma-norma maka masyarakat akan segera membuat suatu upacara yang gunanya untuk menyeimbangkan agar keadaan bisa dinetralisir. Oleh sebab itu nilai dan norma yang ada di Bali sampai sekarang masih tetap eksis.

\section{Stratifikasi Sosial}

Di Desa Penglipuran hanya terdapat satu tingkatan kasta, yaitu Kasta Sudra. Seluruh 
warga masyarakat Desa Panglipuran berasal dari kasta Sudra sehingga mereka memiliki kedudukan yang setara antar warganya. Masyarakat di Desa Penglipuran ini tidak terlalu memandang kasta dan segala macamnya terkait dengan stratifikasi sosial. Mereka percaya bahwa keselarasan dan kesetaraan akan membawa pada kehidupan yang damai dan tentram. Oleh karena hal ini, dalam kehidupan sehari-hari mereka mengidentifikasikan diri mereka sebagai kaum sudra dimana hubungan antara satu orang ke yang lainnya adalah sama tanpa ada tingkatan.

\section{Diferensiasi Sosial}

Masyarakat Desa Adat Penglipuran merupakan satu kelompok masyarakat Bali (Bali Mula) yang menganut Agama Hindu Masyarakat Desa Penglipuran masih tetap mempertahankan tempat-tempat suci (pura) dan ritual tradisional warisan nenek moyang mereka. Desa Penglipuran memiliki bahasa yang tidak jauh berbeda dengan masyarakat Bali pada umumnya. Di Bali sendiri Bahasa Bali memiliki tingkatan penggunaannya, misalnya ada yang di sebut Bali Alus, Bali Madya, dan Bali Kasar. Bahasa yang halus digunakan untuk berkomunikasi secara formal misalnya dalam pertemuan di tingkat desa adat, meminang wanita, atau antara orang berkasta rendah dengan orang yang berkasta lebih tinggi. Bahasa madya digunakan ditingkat masyarakat menengah misalnya atasan kepada bawahannya, sedangkan bahasa bali kasar dipergunakan untuk berkomunikasi oleh orang kelas rendah misalnya kaum sudra atau antara bangsawan kepada abdi dalemnya.

\section{Lembaga/Organisasi/Kelompok Sosial}

Organisasi sosial kemasyarakatan di Desa Penglipuran dapat digolongkan menjadi dua, yaitu Lembaga Desa Pakraman Penglipuran dan Lembaga Dinas Lingkungan Penglipuran. Lembaga Desa Pakraman Penglipuran bersifat otonom karena tidak secara langsung berkaitan dengan lembaga pemerintahan dinas (kelurahan maupun lingkungan). Hubungan lembaga desa pakraman dengan lembaga pemerintahan dinas hanyalah hubungan yang bersifat konsultatif.

Sistem pemerintahan di Lembaga Desa Pakraman Penglipuran disusun dalam satu kepemimpinan adat yang disebut Prajuru Desa
Adat Penglipuran. Prajuru (pengurus) Desa Adat di Penglipuran ini dibedakan menjadi dua bagian, yakni prajuru desa adat dan prajuru ulu apad. Prajuru Desa Adat terdiri atas Bendesa atau kelihan adat, dua orang penyarikan, dan seka-seka. Sedangkan prajuru ulu apad terdiri atas dua belas orang yang disebut dengan Jero Kancan Roras meliputi dua Jero Bayan (Jero Bayan Mucuk dan Jero Bayan Nyoman), dua orang Jero Bahu (Jero Bahu Mucuk dan Jero Bahu Nyoman), dua orang Jero Singgukan (Jero Singgukan Mucuk dan Jero Singgukan Nyoman), dua orang Jero Cacar (Jero Cacar Mucuk dan Jero Cacar Nyoman), dua orang Jero Balung (Jero Balung Mucuk dan Jero Balung Nyoman), dan dua orang Jero Pati (Jero Pati Mucuk dan Jero Pati Nyoman)

Berikut ini bagan struktur lembaga adat Desa Penglipuran:

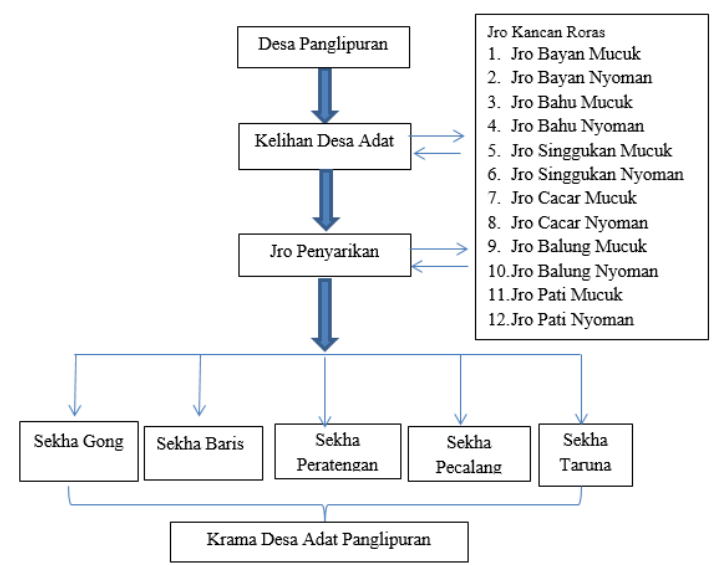

Gambar 1. Bagan Struktur Pemerintahan Adat Desa Penglipuran

Pelaksanaan tugas dan kewajiban sebagai prajuru desa adat diatur dalam awig-awig Desa Adat Penglipuran. Awig-awig merupakan peraturan-peraturan hidup bagi sesama krama desa di desa adatnya untuk mewujudkan kehidupan yang tentram, aman, tertib dan sejahtera (Ngurah Oka, 2000: 25). Lembaga Dinas Lingkungan Penglipuran dipimpin oleh kepala lingkungan. Struktur Lembaga Dinas Lingkungan Penglipuran adalah sebagai berikut:

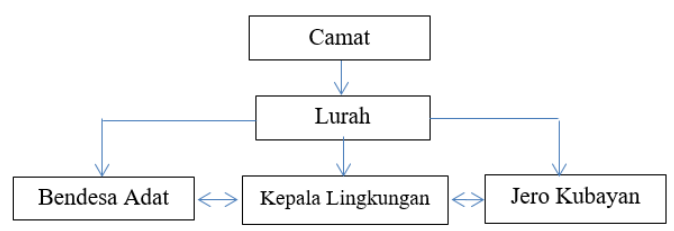


Gambar 2. Bagan Pemerintah Dinas Desa Penglipuran

Tugas dan Fungsi kepala lingkungan adalah sebagai perpanjangan tangan pemerintah kelurahan dalam memberikan pelayanan administrasi pemerintahan kepada masyarakat lingkungan Penglipuran dan melakukan koordinasi dengan struktur lembaga Desa Adat Penglipuran. Kepala lingkungan di Desa Penglipuran dipilih oleh warga masyarakat melalui pemilihan langsung.

\section{Sistem Pernikahan}

Di Desa Penglipuran terdapat adat yang berlaku terkait pernikahan yakni pelarangan poligami terhadap penduduknya. Apabila terdapat warga yang melakukan poligami maka ia akan mendapatkan sanksi. Sanksi yang diberikan berupa pengasingan, dimana warga yang melakukan poligami akan ditempatkan di tempat yang bernama Karang Memadu. Dan dilarang melakukan perjalanan dari selatan ke utara karena wilayah utara bagi orang Penglipuran adalah wilayah yang paling suci. Mereka hanya boleh melewati jalan di selatan Bale kulkul (bangunan tinggi tempat kentongan) desa. Masyarakat Penglipuran juga memiliki pantangan untuk menikahi tetangga yang bertempat tinggal di sebelah kanan dan sebelah kiri juga sebelah depan dari rumahnya. Hal tersebut dikarenakan tetangga yang berlokasi di sekitar rumahnya sudah dianggap sebagai keluarga sendiri.

Bagi warga desa yang ingin menikah dengan orang di luar Desa Penglipuran boleh saja dilakukan. Namun, hal tersebut terdapat ketentuannya yaitu apabila mempelai laki-laki berasal dari Desa Penglipuran maka mempelai perempuan yang berasal dari daerah lain harus masuk menjadi bagian dari adat Penglipuran. Akan tetapi jika mempelai perempuan yang berasal dari desa Penglipuran dan mempelai lakilaki berasal dari adat yang lain, maka bisa saja laki-laki tersebut masuk ke dalam adat Penglipuran dan hidup di Desa Penglipuran tetapi dengan konsekuensi laki-laki tersebut dianggap wanita oleh warga lainnya. Maksudnya yaitu tugas-tugas adat yang dilaksanakan adalah tugas untuk para wanita bukan tugas para lelaki.

\section{Sistem Kekerabatan}

Sistem kekerabatan di Desa Penglipuran mengikuti prinsip patrilineal, artinya hubungan kekerabatan diperhitungkan menurut garis keturunan ayah (Koentjaraninggrat, 1980: 68). Sebagian penduduk Desa Penglipuran terikat hubungan darah akibat perkawinan yang dilakukan sesama warga atau endogami desa. Bagi laki-laki yang menikahi gadis dari keluarga asal yang berbeda, maka dia tetap terikat dalam hak dan kewajibannya pada lingkup kekerabatan keluarga asalnya yang disebut dengan istilah dadia. Sedangkan bagi wanita yang menikahi keluarga asal yang berbeda akan dengan sendirinya mengikuti keluarga asal suaminya.

\section{Sistem Mata Pencaharian}

Dilihat dari mata pencaharian, masyarakat Desa Penglipuran memiliki mata pencaharian yang bervariasi sebagaimana dapat dilihat pada tabel berikut:

Tabel 1. Data Mata Pencaharian Penduduk

\begin{tabular}{cll}
\hline No & Jenis Mata Pencaharian & Jumlah Penduduk \\
\hline 1 & Petani & 48 Orang \\
2 & TNI/POLRI & 6 Orang \\
3 & PNS & 26 Orang \\
4 & Guru & 15 Orang \\
5 & Pensiunan PNS & 13 Orang \\
6 & Bidan & 2 Orang \\
7 & Tukang & 33 Orang \\
8 & Perajin bambu & 17 Orang \\
9 & Perajin Makanan & 24 Orang \\
10 & Perajin Loloh & 15 Orang \\
& Cemcem/kunyit & \\
11 & Karyawan & 41 Orang \\
12 & Buruh & 76 Orang \\
13 & Pedagang & 149 Orang \\
14 & Kapal Pesiar & 35 Orang \\
15 & Peternak & 8 Orang \\
16 & Penjahit & 6 Orang \\
17 & Pelukis & 3 Orang \\
18 & Perajin Kayu & 8 Orang \\
19 & Jasa Laundry & 2 Orang \\
20 & Veteran yang mendapat & 16 Orang \\
& TUVET & \\
\hline &
\end{tabular}

Sumber: Profil Desa Penglipuran, 2021

Berdasar tabel 1 mata pencaharian utama masyarakat di Desa Penglipuran adalah sebagai pedagang dan buruh. Selain itu masyarakat di 
Desa penglipuran juga sudah mulai tertarik dengan pekerjaan di bidang kepariwisataan seperti bekerja di kapal pesiar. Hal ini menunjukkan adanya peralihan jenis pekerjaan penduduk, yang semula hanya bergelut di bidang pedagang dan buruh menuju bidang kepariwisataan.

\section{Sistem Pengetahuan}

Generasi muda Penglipuran sudah mengenyam pendidikan formal mulai dari SD hingga pendidikan tinggi, dan mereka tetap melestarikan tradisi yang mereka warisi dari para leluhurnya. Sistem pendidikan di Desa Adat Penglipuran sudah cukup maju yaitu ditandai dengan banyak para pemuda yang mengenyam pendidikan sampai jenjang yang tinggi, bahkan tidak sedikit dari mereka yang melanjutkan pendidikan ke luar kota. Di pintu masuk desa Penglipuran ada sebuah sekolah sejenis dengan Taman Kanak-Kanak. Hal ini menjadi sedikit bukti bahwa di Desa Penglipuran sistem pengetahuannya sudah maju. Berikut ini data lulusan masyarakat di Desa Penglipuran:

Tabel 2. Data Lulusan Penduduk Desa

Penglipuran

\begin{tabular}{ll}
\hline Lulusan & Jumlah Penduduk \\
\hline Buta huruf & 7 \\
Tidak tamat SD & 18 \\
Tamat SD & 300 \\
Tamat SLTP & 195 \\
Tamat SLTA & 270 \\
Tamat D1 & 16 \\
Tamat D2 & 30 \\
Tamat D3 & 13 \\
Tamat S1 & 60 \\
Tamat S2 & 2 \\
\hline
\end{tabular}

Sumber: Profil Desa Adat Panglipuran, 2021

\section{Sistem Teknologi dan Peralatan}

Desa panglipuran merupakan desa yang terbuka dengan teknologi yang ada, seperti handphone, gadget maupun televisi. Desa Penglipuran sudah teraliri listrik, air PDAM, bahkan tidak sedikit yang memiliki kendaraan mewah seperti mobil, namun kendaraan tersebut hanya bisa dioperasikan setiap pukul 17.00 hingga malam hari. Air kotor pada Desa Penglipuran yang dihasilkan masing-masing rumah tangga langsung ditampung ke septic tank (limbah padat), sedangkan limbah cair dibuang ke selokan yang dihubungkan melalui pipa-pipa. Jaringan air bersih yang digunakan untuk mencukupi konsumsi air bersih pada Desa Penglipuran berasal dari PDAM. Sistem penghawaan pada Desa Penglipuran menggunakan sistem penghawaan alami berupa jendela dan lubang dinding lainnya yang juga memanfaatkan terang langit sebagai media penerangan pada siang hari.

Perkembangan teknologi juga terlihat melalui pekerjaan masyarakat sehari-hari. Pada saat bercocok tanam, masyarakat Desa Penglipuran dalam membajak sawahnya sudah menggunakan peralatan yang canggih yakni traktor. Contoh lainnya yaitu dalam pembuatan minuman khas Desa Penglipuran yang dulu menggunakan alat tumbuk, setelah listrik masuk ke desa ini mesin tumbuk digantikan dengan mesin yang sudah modern yaitu mesin giling sehingga mempengaruhi proses produksi yang lebih cepat.

Masuknya teknologi di Desa Penglipuran masyarakat tersebut menyikapinya dengan sangat berterimakasih kepada pihak pemerintah yang sudah menyuplai listrik di desa Penglipuran masyarakat juga tidak ketergantungan dengan teknologi yang semakin canggih walaupun sudah ada handphone akan tetapi masyarakat di desa tersebut tetap bersosialisasi contohnya pada saat kami meneliti Desa Panglipuran ibu-ibu rumah tangga berkumpul di semua aula untuk pertemuan pkk dimana setiap individu membawa satu kantong plastik yang berisi sampah.

\section{Dinamika Budaya Adat Desa Penglipuran Adat Istiadat}

Dalam ajaran agama Hindu seluruh jenis upacara pada umumnya di Bali dan Penglipuran khususnya, digolongkan ke dalam lima komponen yang terstruktur yakni disebut dengan panca yadnya, dalam arti harfiahnya panca artinya lima dan yadnya artinya korban suci. Adapun lima komponen dari panca yadnya yaitu:

1. Manusia yadnya, yaitu meliputi upacara daur hidup dari masa bayi masih dalam kandungan sampai dewasa. 
2. Pitra yadnya, yaitu : merupakan upacara yang ditunjukan kepada roh-roh leluhur, meliputi upacara kematian sampai pada upacara penyucian roh leluhur.

3. Dewa yadnya, yaitu upacara yang dilakukan di pura umum seperti Tri Kahyangan Tiga mapun pura Jagat (pura umum) maupun yang lebih kecil adalah upacara yang dijalankan di pura keluarga.

4. Resi yadnya, merupakan upacara yang berhubungan dengan pentasbihan pendeta.

5. Bhuta yadnya, meliputi upacara yang ditunjukan kepada bhuta dan kala, yaitu roh-roh halus, yang ada dialam dan disekitar manusia sehingga tidak menggangu kehidupan manusia.

Lima komponen tersebut di atas, menjadi pedoman dalam melaksanakan kewajibankewajiban yang tentunya bertujuan untuk mendapatkan keselamatan, kemakmuran atau kesejahteraan terhadap Tuhan.

Tahapan pelaksanaan pemakaman di Desa Penglipuran yaitu masyarakat desa akan membunyikan kentongan beberapa kali sebagai tanda berita duka. Seusai terdengar kentongan berbunyi, selanjutnya para tokoh dan pemuka adat berkumpul mencari hari baik kapan waktunya untuk pelaksanaan penguburan mayat. Setelah hari baik disepakati baru dilaksanakan upacara memandikan mayat, setelah itu mayat ditempatkan di Bale dengan arsitektur Bali kuno. Jika waktunya tiba, mayat pun diusung ke kuburan desa yang terletak di ujung sebelah barat. Saat berjalan ke kuburan tidak menggunakan banten ataupun sesajen, dan mayat langsung dibawa ke kuburan oleh kerabatnya. kemudian mengusung kembali mayat yang telah dibersihkan, setelah itu diputar sebanyak sebelas kali ke arah kanan. mayat yang sudah tidak memakai pakaianpun dimasukkan ke dalam kuburan yang sudah disediakan warga sebelumnya. Prosesi tradisi tersebut bertujuan untuk menghormati maha kuasa atas keberkahan hidup selama di dunia ini dan jika pada waktu meninggal, kembali kepada yang maha kuasa dengan sikap sopan dan suci. Tradisi tersebut tetap dilaksanakan dan tidak akan pernah ketinggalan sedikitpun.
Penguburan mayat dengan cara ditengadahkan untuk mayat perempuan dan ditelungkupkan untuk mayat laki-laki memiliki filosofi tersendiri. Posisi menengadah atau yang dalam bahasa bali di isitilahkan dengan posisi nungkayak untuk mayat perempuan melambangkan ibu pertiwi (bumi). Sedangkan posisi telungkup atau yang dalam istilah Bali melinggeb untuk mayat laki-laki, melambangkan akasa (angkasa). Saat dikubur posisi kepala mayat baik perempuan maupun laki-laki samasama diposisikan di arah barat atau arah matahari terbenam. "Kenapa seperti itu, karena lokasi Pura Dalem Pingit berada di delod kauh (barat daya). Makanya mayat di kubur berorientasi ke barat kearah mata hari terbenam. Kuburan di Desa Penglipuran dibedakan menjadi tiga. Kuburan yang berada paling timur diperuntukan khusus untuk memakamkan warga yang meninggal karena tidak wajar seperti bunuh diri dan sejenisnya (salah pati ataupun ulah pati). Sementara yang di tengah diperuntukan untuk memakamkan bayi dan orang dewasa yang belum menikah. Sedangkan yang paling kauh (barat) diperuntukan untuk mengubur warga yang meninggal secara wajar.Tradisi tersebut masih bertahan hingga saat ini dikarenakan sejak turun -temurun dari generasi ke generasi tetap dilakukan dan tidak pernah di lupakan oleh masyarakat desa Penglipuran. Tradisi tersebut dilakukan jika salah satu anggota keluarga ada yang meninggal di desa tersebut dan warga asli desa panglipuran.

\section{Hukum Adat}

Di Desa Penglipuran memiliki peraturan adat tersendiri. Peraturan ini disebut dengan Awig-awig. Awig-awig ini antara lain mengatur tentang:

1) Aturan adat mengenai pernikahan

Satu-satunya kebudayaan Desa

Penglipuran yang masih dipertahankan adalah larangan bertindak poligami. Larangan ini benar-benar diperkuat dengan hukuman yang sudah diatur oleh aturan adat setempat. Apabila ada salah satu warga Desa Panglipuran yang melakukan poligami, maka orang tersebut akan diasingkan ke dalam suatu tempat yang jauh dari Desa 
Panglipuran. Tempat itu mirip dengan pondok khusus dan bisanya disebut dengan 'Pemadu'. Untuk sistem pewarisan di Desa Penglipuran sendiri apabila sudah bercerai atau tidak menikah maka sang istri mempunyai hak yaitu harta dibagi rata dengan mantan suami,hutang termasuk gono-gini jika bercerai, sang istri diberi uang modal senagai membuka usaha kecilkecilan.

2) Aturan mengenai desain dan model rumah

Berdarsarkan informasi jelajah yang diperoleh dari I wayan Supat, keunikan desain dan model rumah yang ada di desa ini patut dibanggakan. Pasalnya, di beberapa pintu rumah juga ada ukiran dan beberapa relief yang menarik. Uniknya lagi, di dalam satu pintu tersebut dihuni oleh macammacam kepala keluarga yang masih memiliki satu ikatan keturunan. Sedangkan di luar rumah juga terdapat dapur yang terpisah dengan tempat tinggal. Akses pintu masuk dan keluar di dalam rumah ini juga sama pula.

Menurut I Wayan Supat dugaan, desain rumah ini dibuat sedemikian rupa untuk mengumpulkan saudara yang memiliki satu ikatan keturunan darah yang sama dalam satu keluarga. Dengan aturan seperti ini, para warga tidak akan kebingungan dalam mengumpulkan saudara mereka sehingga tidak khawatir tertukar atau menyukai lawan jenis yang masih sedarah. Saya pikir aturan ini memang bagus agar kita bisa lebih dekat dengan keluarga kita sendiri. 3) Aturan mengenai tempat peribadatan

Salah satu hasil informasi dari I wayan Supat menyebutkan bahwa setiap rumah kebanyakan memiliki bangunan pura yang lebih besar. Namun, tidak semua orang bisa beribadah di pura tempat orang lain walaupun mereka sesama beragama Hindu. Orang-orang yang boleh beribadah di pura tersebut adalah keluarga penghuni rumah itu sendiri dan saudara-saudaranya yang memiliki ikatan keturunan darah. Keberadaan hukum di Desa Penglipuran masih sangat di pegang erat pada era globalisasi sekarang dan masih masih diterapkan dalam kehidupan sehari-hari berbangsa dan bernegara.

Banyak tantangan bagi masyarakat adat, termasuk lembaga-lembaga adatnya terutama dalam menjalankan fungsinya. Tantangan yang dihadapi tersebut antara lain telah terjadinya perubahan nilai orientasi warga masyarakat dalam bersikap dan bertindak. Statergi yang dapat dilakukan ialah dengan menaati seluruh peraturan atau awig-awig yang sudah di sepakati bersama.untuk cara pelestarian hukum adat tersebut masyarakat tetap menjalankan sistem peraturan dan dikenakan sanksi pabi yang melanggar peraturan atau awig-awig tersebut.

\section{Kesenian}

Bali merupakan salah satu provinsi yang kaya akan keseniannya. Kekayaan budaya inilah yang menjadi daya tarik wisatawan baik domestik maupun mancanegara. Bagai masyarakat Desa Penglipuran kesenian merupakan bagian dari jiwa mereka. Karena unsur agama terdapat makna yang mendalam pada setiap kesenian yang disajikan. Kesenian di Desa Penglipuran ini tidaka hanya sebagai sebuah seni semata tetapi juga dijadikan sebagai sebuah profesi meskipun hanya sebuah profesi sampingan.

Desa Penglipuran terdapat sebuah tarian yang di sebut tari Baris. Tari Baris merupakan bentuk kesenian tradisional yang berakar kuat pada kehidupan masyarakatnya dan diwariskan secara turun temurun dari generasi ke genarasi. Tari Baris ini merupakan tarian sakral yang berfungsi sebagai tarian dan penyelenggaraan upacara Dewa Yadnya atau upacara pemujaan yang ditujukan kepada Tuhan.

Para penari Baris yang ada di Desa Penglipuran terdiri dari penari Baris Jojor yang berjumlah enam belas orang, mereka adalah anggota masyarakat yang belum menikah yang tergabung dalam Sekaa Teruna Teruni. Penari Baris Presi berjumlah empat orang, sedangkan keaanggotaan sekaa penari Baris Presi ini berjumlah dua belas orang dan mereka adalah yang sudah berkeluarga, tetapi berstatus "pengahayah pengerob". Penari Baris Bedil 
berjumlah enam belas orang, dan keanggotan sekaa Baris Bedil ini berjumlah dua puluh orang. Ketiga jenis tarian Baris tersebut di atas adalah merupakan tari-tarian sakral yang hanya dapat ditarikan oleh orang laki-laki saja, yang dalam pementasannya diiringi dengan gamelan gong gede oleh sekaa gong Desa Adat Penglipuran.

\section{SIMPULAN}

Desa Penglipuran memiliki banyak tradisi yang sampai sekarang masih dilaksankan. Tradisi tersebut seperti tradisi pernikahan, yakni pelarangan poligami terhadap penduduknya. Apabila terdapat warga yang melakukan poligami maka ia akan mendapatkan sanksi. Sanksi yang diberikan berupa pengasingan, dimana warga yang melakukan poligami akan ditempatkan di tempat yang bernama Karang Memadu. Peraturan tersebut masih bertahan samapi sekarang, meskipun belum ada yang pernah tinggal di Karang Memadu tersebut. Sistem kekerabatan di Desa Penglipuran mengikuti prinsip patrilineal, artinya hubungan kekerabatan diperhitungkan menurut garis keturunan ayah sebenarnya desa panglipuran merupakan desa yang terbuka akan teknologi dan masyarakat di desa panglipuran sudah melek terhadap teknologi.

Banyaknya penduduk Desa Penglipuran, khususnya pemuda yang merantau ke luar desa bahkan ke luar pulau untuk memperoleh pengalaman baru dan pengetahuan yang justru menjadi tantangan bagi desa Penglipuran. Beberapa tradisi yang melibatkan pemuda setempat akan mulai terancam karena adanya migrasi yang dilakukan. Oleh karena itu, pemerintah Pusat harus bekerja sama dengan pihak sekolah atau tempat kerja untuk ikut serta dalam mempertahankan tradisi yang ada di Desa Penglipuran dengan membuat peraturan untuk meliburkan pelajar dan/atau pekerja yang berasal dari kedua desa tersebut ketika kegiatan tradisi hendak dilaksanakan.

\section{DAFTAR PUSTAKA}

Arsana, I. G. (2002). Pembudayaan Nilai-Nilai Budaya Dalam Rangka Mewujudkan Keluarga Sejahtera Derah Bali. Denpasar : BP Kebudayaan dan Pariwisata, Deputiidang Pelestarian dan Pengembangan Kebudayaan .

Nurhaidah, M. Insya Musa. 2015. "Dampak Pengaruh Globalisasi Bagi Kehidupan Bangsa Indonesia". JURNAL PESONADASARVol. 3 No. 3, April 2015, hal 1-14ISSN:2337-9227

Rahmawati, Ayu Diasti (et. al.). 2010. "Globalisasi Budaya dan Bahasa Indonesia Sebagai Indentitas Bangsa". Multiversa, Journal of International Studies, Vol 1 No1.

Suneki, Sri. 2012. "Dampak Globalisasi Terhadap Eksistensi Budaya Daerah". Jurnal Ilmiah CIVIS, Volume II, No 1, Januari 2012. 